AperTO - Archivio Istituzionale Open Access dell'Università di Torino

\title{
Behavioral correlates of extra-pair copulation in Indri indri
}

\section{This is the author's manuscript}

Original Citation:

\section{Availability:}

This version is available http://hdl.handle.net/2318/138580

since 2016-05-06T13:28:08Z

Published version:

DOI:10.1007/s10329-013-0376-0

Terms of use:

Open Access

Anyone can freely access the full text of works made available as "Open Access". Works made available under a Creative Commons license can be used according to the terms and conditions of said license. Use of all other works requires consent of the right holder (author or publisher) if not exempted from copyright protection by the applicable law. 


\title{
Behavioral correlates of extra-pair copulation in Indri indri
}

Giovanna Bonadonna ${ }^{1} \cdot$ Valeria Torti ${ }^{1} \cdot$ Rose Marie Randrianarison $^{2} \cdot$ Nicole Martinet $^{1} \cdot$ Marco $\mathrm{Gamba}^{1} \cdot$ Cristina Giacoma ${ }^{1}$

${ }^{1}$ Department of Life Sciences and Systems Biology, University of Torino, Via Accademia Albertina 13,10123 , Torino, Italy

${ }^{2}$ GERP (Group d'Étude et de Recherche sur les Primates de Madagascar), Fort Duchesne, Antananarivo 101, Madagascar

\begin{abstract}
Active pursuit of extra-pair mating has been reported for Indri indri, the socially monogamous largest living lemur. This study, conducted in a mountain rainforest in eastern Madagascar, presents the first evidence for extra-pair mating of indri and discusses the alternative mating strategy and alteration of the social, territorial, spatial, and vocal behavior of the adult female of a group of wild indris. Further studies may investigate whether extra-pair copulation is an attempt to breed with a partner of superior quality and thus lead to extra-pair paternity. If so, it could potentially play a role in maintaining genetic variability within a population.
\end{abstract}

Keywords Extra-pair copulation Indri indri Monogamy Spatial behavior Vocal behavior

\section{Introduction}

Monogamy is limited to $5 \%$ of extant living mammalian species (Kleiman 1977). According to Trivers (1972) monogamy is common in birds because parental care may be shared by both sexes. Polygyny, on the other hand, is most likely to occur in mammals, in which parental care is mainly borne by females. Males, less involved in parental care, may incur fewer costs in engaging in additional matings, but it is also known that paternal care is a poor predictor of monogamy in primates (Wright 1990; Tardif 1994; Komers and Brotherton 1997). To increase their reproductive success, males must gain access to as many females as possible, but if complete monopolization is not possible males must maximize their number of copulations (Kappeler and Van Schaik 2004) coercing females (Isbell and Van Vuren 1996; Packer 1979; Samuels et al. 1984; Shively and Smith 1985; Bercovitch 1988) or pursuing extra-pair copulations (EPCs) (Trivers 1972). However, the benefits a male may gain from EPCs must reconcile:

(1) The costs of pursuing such additional matings; and

(2) The gains from parental efforts (Maynard Smith 1977; Westneat et al. 1990)

such that male reproductive behavior may be seen as a tradeoff between mating and parental effort. 
Previous studies of birds (Wagner 1991; Kempenaers et al. 1992; Birkhead and Møller 1992; Kempenaers and Dhondt 1993) have shown that extra-pair paternity is likely to be largely controlled by females, which may resist, accept, and/or actively seek EPCs (Westneat et al. 1990). Females may gain genotypic benefits from initiating extra- pair mating: in particular, "good genes", increased heterozygosity of their offspring, or fertilization insurance (Westneat et al. 1990). By actively seeking an EPC a female may copulate with a higher quality reproductive partner, if its mate is not the best available partner (Gray 1997).

The occurrence of EPC has been documented for several socially monogamous mammal species (Isvaran and Clutton-Brock 2007), including primates (gibbons: Palombit1994b; Oka and Takenaka 2001; marmosets: Digby 1999; dwarf lemurs: Fietz et al. 2000; sifakas: Lawler 2007; fork-marked lemurs: Schulke et al. 2004; and red-bellied titis: Mason 1966). It has never been observed for indri (Indri indri), a socially monogamous primate (Pollock 1975a, b; Reichard and Boesch 2003) inhabiting the mountain rainforests of eastern Madagascar and living in territorial family groups typically consisting of a breeding pair and their offspring (Petter and Peyriéras 1979; Pollock 1975a, b, 1979; Powzyk and Thalmann 2003). Indri family groups, actively defend their territories both through direct fights at the boundaries and by singing. The indris' song is a long sequence of vocal utterances (Pollock 1986; Giacoma et al. 2010; Gamba et al. 2011; Sorrentino et al. 2013) that serve to regulate spacing between neighboring groups and maintain group cohesion (Pollock 1986; Torti et al. 2010). The mating season usually lasts from late November to February (Pollock 1975a, b), but breeding behavior is more often observed in December and January, when territorial behavior, social interactions, and the timing and frequency of indri singing activity steadily increase (Pollock 1975a, b, 1986); Mittermeier et al. 2006).

In this paper we report an EPC, observed for the first time in this species, during a long-term field study. We provide a detailed description of the social, singing, and spatial behavior of an indri group before, during, and after the EPC.

\section{Methods}

Study area and subjects

The Maromizaha forest $\left(18^{\circ} 5604900 \mathrm{~S}-48^{\circ} 2703300 \mathrm{E}\right)$ is 1880.8 hectares in size, extending around the village of Anevoka, in eastern Madagascar, $29.6 \mathrm{~km}$ east of Moramanga, province of Toamasina, in the Alaotra Mangoro region (Hervieu 1960). We observed a habituated group of indris (designated 3MZ) for a total of $143 \mathrm{~h}$ and $19 \mathrm{~min}$, during 23 days of sampling activity, between October 10, 2011 and December 16, 2011. The group was composed of an adult breeding couple, a sub-adult male, and a juvenile. The male involved in the EPC was from a wild, non-habituated group (designated XMZ). We found group XMZ twice before the day of the EPC. This enabled us to identify its composition: an adult male, an adult female, and a juvenile (born in 2011). We carried out observations daily from 06:00 to 13:00 h, the most active period for indris (Pollock 1975a, b).

\section{Behavioral observations}

Behavioral data were collected by using the focal animal sampling method (Altmann 1974). Each day, each researcher followed a focal animal using a 30-s scan every 5 min and collected data on distance between the study subjects and on displayed behavior (additional data are provided in

Electronic supplementary material. The online version of this article (doi:10.1007/s10329-013-0376-0) contains supplementary material, which is available to authorized users 
Online Resource 1). We termed advertisement song the indris' song used for territorial announcement (Pollock 1986; Torti et al. 2010). We randomly chose focal animals, to enable equal sampling of all the individuals during the study period. We followed a group for a maximum of five consecutive days, according to its detectability. We conducted all-occurrences sampling (Altmann 1974) of selected behavior, for example aggressive interactions, geophagy, and marking.

For this research we had the research permit 2011 (no. 274/11/MEF/SG/DGF/DCB.SAP/SCB), from the Direction des Eaux et Forets, Antananarivo, Madagascar.

\section{Results}

Indri family groups occupy exclusive territories whose shape and extent is directly regulated through inter-group encounters at the boundaries of the territories. In 2010, 3MZ's home range size was 12.09 hectares (Torti 2013). In 2011, we observed a shift in group 3MZ's spatial distribution, with a loss of 2.66 hectares of the northwestern portion of the territory along the boundaries with group XMZ (unpublished data).

On December 7, at 8:00 am, group 3MZ was found in the eastern part of its territory (additional data are provided in Online Resource 2). We noticed sexual approaches between the resident adult male and the adult female of group 3MZ. When the male sexually approached, the female rejected and moved away using vertical clinging and leaping jump. During the day, the adult male was vigilant and kept a short distance from the female. Every time the female interacted with the sub-adult male the adult male moved towards them.

On December 12, the group moved toward the western portion of its territory and we saw the female making ano-genital $(\mathrm{N}=8)$ and cheek marks $(\mathrm{N}=11)$.

On December 13, at 9:00 am, we found the female outside the boundaries of 3MZ territory, alone in the territory of the neighboring group XMZ. The juvenile and the sub-adult male from $3 \mathrm{MZ}$ were in their own territory, approximately $50 \mathrm{~m}$ away from the female. Between 9:00 am and 9:40 am, the female changed her location to eat Tavolo manitra fruits and uttered kiss-wheeze vocalizations (Maretti et al. 2010) at 9:19 am and 9:21 am. At 9:40 am the female moved toward a Menahihy tree and began an advertisement song, the adult male of 3MZ (approx. $15 \mathrm{~m}$ away) participated in singing. The female was at rest until 9:53 am, then moved $15 \mathrm{~m}$ away to a Hetatra tree, where at 10:00 am the adult male of the group XMZ suddenly and rapidly reached her. This male immediately approached the female, first sitting just behind her on the same branch, and then mating with her. The female did not try to reject him, as she had previously rejected the adult male of her group. At 10:02 am the male XMZ stopped mating and moved. Immediately after, the female followed the XMZ male, but shortly after that we heard an advertisement song coming from XMZ's territory, and the female moved back in the direction of her own territory. The male of group XMZ sang together with the other members of group XMZ. We were not able to identify the other callers of group $\mathrm{XMZ}$ because the animals were far away and not visible and we continued to follow the female of group 3MZ. Immediately after hearing the neighbors' song, the adult male and the sub-adult male of group $3 \mathrm{MZ}$ started an advertisement song in their own territory, but the female did not participate. Of the 34 songs recorded in study period this was the only song that the female of group $3 \mathrm{MZ}$ did not take part in. Indeed, apart from this instance, we always observed the adult couple singing together. At 12:05 pm, the sub-adult of group $3 \mathrm{MZ}$ uttered roars and then the adult male and female of $3 \mathrm{MZ}$ simultaneously emitted an advertisement song. The sub-adult and the juvenile came closer to the female and the adult male, which had always been far from the group, stayed $20-30 \mathrm{~m}$ from 
the female for the rest of the day. The female of group $3 \mathrm{MZ}$ made fewer ano-genital $(\mathrm{N}=1)$ and cheek marks $(\mathrm{N}=2)$ on December 13 than on the previous day.

On December 16, the amount of marking was comparable with that observed on December 13 (anogenital $\mathrm{N}=2$, cheek marks $\mathrm{N}=2$ ).

\section{Discussion}

Our study reports an EPC in indri, which is a deviation from their usual pattern of social, territorial, spatial, and vocal behavior. The female, unusually, moved away from her offspring, entered the territory of a neighboring group and did not join her male singing when outside their occupied territory. The obligate monogamous breeding system of indris seems more flexible than expected from early studies, similar to that observed for gibbons (Palombit 1994a; Reichard 1995; Brockelman et al. 1998). The behavior of the adult male of group XMZ reflects the hypothesis of a mixed reproductive strategy in this species. Engaging in an EPC may produce benefits for both the female, in terms of selection of a fitter male, and for the male, in that he will sire more offspring (Fisher 1930; Zahavi 1975; Hamilton and Zuk 1982). When females are not fertilizable simultaneously (female estrus asynchrony), more mating partners are available for males during the breeding season (Matsumoto-Oda et al. 2007).

The male of group XMZ may also have engaged in EPC to maximize his reproductive success by copulating with a potentially receptive female. The adult female of group XMZ may have been unreceptive because she gave birth the year before, whereas the $3 \mathrm{MZ}$ female was 2 years postparturition and thus potentially receptive (Pollock 1975a, b).

On the other hand, females may copulate with extra-pair males because of their genetic quality, gaining indirect genotypic benefits from EPC, for example better genes and increased genetic variability of the offspring (Smith 1988; Lawler 2007). Females may also gain direct benefits, e.g. gaining tolerance of the neighboring male when defending his territory from intrusion (Barlow 1970) or increasing mate guarding by her own male (Kempenaers and Dhondt 1993).

The existence of EPC in indris may lead to re-assessment of the mating strategy of this species. We submit that EPC between individuals of different groups is potentially underestimated, because it is difficult to detect, and that researchers need to increase knowledge about the behavioral and genetic consequences of EPC.

\section{Acknowledgments}

This occurrence of EPC was recorded during a larger field study of Indri indri supported by the Universita' degli Studi di Torino and the ACP Science and Technology Programme of the ACP Group of States, with the financial assistance of the European Union, through the Projects BIRD (Biodiversity Integration and Rural Development; no. FED/2009/217077) and SCORE (Supporting Cooperation for Research and Education; Contract no. ACP RPR 118 \# 36) and by grants from the Parco Natura Viva - Centro Tutela Specie Minacciate. We are grateful to Compagnia di San Paolo for co-financing the "Progetto 2008-10 Innovazione Laboratori didattici - Facolta' di Scienze MFN' "which enabled the purchase of laboratory equipment used by G.B. and V.T. during field activity. We thank the Ministère de l'Environnement et des Forets (MEF) and Madagascar National Parks for granting the research permits. We are also grateful to GERP (Groupe d'Etudes et des Recherche sur les Primates) for allowing us to collect data in the forest under its management. Last, 
we thank Dr Cesare Avesani Zaborra and Dr Caterina Spiezio for their important role in organization of the Maromizaha field station and all the research and international guides, Dr Olivier Friard for helping during data analysis, Lanto and Mamatin for their help and logistic support, Dr Dominic Currie and Dr Caroline Harcourt for linguistic revision and two anonymous referees. The contents of this document are the sole responsibility of the authors and can in no circumstances be regarded as reflecting the position of the European Union.

\section{References}

Altmann J (1974) Observational study of behavior: sampling methods. Behav 49:227-267 [Reprinted in: Houck LD and Drickamer LC (eds) Foundations of Animal Behavior. U Chicago Press, 1996]

Barlow GW (1970) A test of appeasement and arousal hypotheses of courtship behavior in a cichlid fish, Etroplus maculatus. Zeitschrift für Tierpsychologie 27:779-806

Bercovitch FB (1988) Coalitions, cooperation and reproductive tactics among adult male baboons. Anim Behav 36:1198-1209

Birkhead TR, Møller AP (1992) Sperm competition in birds: evolutionary causes and consequences. Academic Press, London Brockelman WY, Reichard U, Treesucon U, Raemaekers JJ (1998) Dispersal, pair formation, and social structure in gibbons (Hylobates lar). Behav Ecol Sociobiol 42:329-339

Digby LJ (1999) Sexual behavior and extragroup copulations in a wild population of common marmosets (Callithrix jacchus). Folia Primatol 70:136-145

Fietz J, Zischler H, Schwiegk C, Tomiuk J, Dausmann KH, Ganzhorn JU (2000) High rates of extra-pair young in the pair-living fat-tailed dwarf lemur, Cheirogaleus medius. Behav Ecol Sociobiol 49:8-17

Fisher RA (1930) The genetical theory of natural selection. Clarendon Press, Oxford

Gamba M, Favaro L, Torti V, Sorrentino V, Giacoma C (2011) Vocal tract flexibility and variation in the vocal output in wild indris. Bioacoustics 20:251-265

Giacoma C, Sorrentino V, Rabarivola C, Gamba M (2010) Sex differences in the song of Indri indri. Int J Primatol 31:4539-4551

Gray EM (1997) Do female red-winged blackbirds benefit genetically from seeking extra-pair copulations? Anim Behav 53:605-623

Hamilton WD, Zuk M (1982) Heritable true fitness and bright birds: a role for parasites? Science 218:384-387

Hervieu J (1960) Notice sur les cartes peédologiques de reconnaissance 1/200000 Feuille n3. Brickaville-Moramanga. IRSM. p 67

Isbell LA, Van Vuren D (1996) Differential costs of locational and social dispersal and their consequences for female group-living primates. Behav 133:1-36 
Isvaran K, Clutton-Brock T (2007) Ecological correlates of extra-group paternity in mammals. Proc Biol Sci 274:219-224

Kappeler PM, van Schaik CP (2004) Sexual selection in primates: review and selective preview. In: Sexual Selection in Primates. Cambridge: Cambridge University Press (Kappeler PM, van Schaik CP eds.) pp 3-23

Kempenaers B, Dhondt AA (1993) Why do females engage in extra-pair copulations? A review of hypotheses and their predictions. Belg J Zool 123:93-103

Kempenaers B, Verheyen GR, Van den Broeck M, Burke T, Van Broeckhoven C, Dhondt AA (1992) Extra-pair paternity results from female preference for high quality males in the blue tit. Nature 357:494-496

Kleiman DG (1977) Monogamy in mammals. Q Rev Biol 52:39-69

Komers PE, Brotherton PN (1997) Female space use is the best predictor of monogamy in mammals. Proc Biol Sci 264:1261-1270

Lawler RR (2007) Fitness and extra-group reproduction in male Verreaux's sifaka: an analysis of reproductive success from 1989-1999. American journal of physical anthropology, Wiley Online Library

Maretti G, Sorrentino V, Finomana A, Gamba M, Giacoma C (2010) Not just a pretty song: an overview of the vocal repertoire of wild indris. J Anthropol Sci 88:151-165

Mason WA (1966) Social organization of the South American monkey, Callicebus moloch: a preliminary report. Tulane Stud Zool 13:23-28

Matsumoto-Oda A, Hamai M, Hayaki H, Hosaka K, Hunt KD, Kasuya E, Kawanaka K, Mitani JC, Norikoshi K, Takasaki H, Takahata Y (2007) Estrus cycle asynchrony in wild female chimpanzees, Pan troglodytes schweinfurthii. Behav Ecol Sociobiol 61:661-668

Maynard Smith J (1977) Parental investment: a prospective analyses. Anim Behav 25:1-7

Mittermeier RA, Konstant WR, Hawkins F, Louis EE, Langrand O, Ratsimbazafy J, Rasoloarison R, Ganzhorn JU et al. (2006) Lemurs of Madagascar. Conservation International 391-403

Møller AP (1990) Sexual behavior is related to badge size in the house sparrow Passer domesticus. Behav Ecol Sociobiol 27:23-29

Oka T, Takenaka O (2001) Wild gibbons' parentage tested by non- invasive DNA sampling and PCR-amplified polymorphic micro- satellites. Primates 42:67-73

Packer C (1979) Male dominance and reproductive activity in Papio anubis. Anim Behav 27:37-45

Palombit RA (1994a) Dynamic pair bonds in hylobatids: implications regarding monogamous social systems. Behaviour 128:65-101

Palombit RA (1994b) Extra-pair copulations in a monogamous ape. Anim Behav 47:721-723 
Petter JJ, Peyrieras CD (1979) Vocal communication in prosimians; the study of prosimian behavior. In: Doyle GA, Martin RD (eds) The study of prosimian behaviour. Academic Press, New York, pp 272-282

Pollock JI (1975a) Field observations on Indri indri: a preliminary report. In: Tattersall I, Sussman RW (eds) Lemur Biology. Plenum Press, New York, pp 287-311

Pollock JI (1975) The social behavior and ecology of Indri indri. PhD thesis, University College London

Pollock JI (1979) Female dominance in Indri indri. Folia Primatol 31:143-164

Pollock JI (1986) The song of the indri (Indri indri; Primates; Lemuroidea): natural history, form, and function. Int J Primatol 7:225-264

Powzyk JA (1997) The socio-ecology of two sympatric indriids: Propithecus diadema diadema and Indri indri. A comparison of feeding strategies and their possible repercussions on species-specific behaviors. Ph.D. dissertation, Duke University, Durham, NC

Powzyk J, Thalmann U (2003) Indri indri, Indri. In: Goodman SM, Benstead JP (eds) The natural history of Madagascar. University of Chicago Press, Chicago, pp 1342-1345

Reichard U (1995) Extra pair copulations in a monogamous gibbon (Hylobates lar). Ethol 100:99112

Reichard UH, Boesch C (2003) Monogamy: mating strategies and partnership in birds, humans and other mammals. Cambridge University Press, Cambridge, p 267

Samuels A, Silk JB, Rodman PS (1984) Changes in the dominance rank and reproductive behaviour of male bonnet macaques (Macaca radiata). Anim Behav 32:994-1003

Schu'lke O, Kappeler PM, Zischler H (2004) Small testes size despite high extra-pair paternity in the pair-living nocturnal primate Phaner furcifer. Behav Ecol Sociobiol 55:292-301

Shively C, Smith DG (1985) Social status and reproductive success of male Macaca fascicularis. Am J Primatol 9:129-135

Smith SM (1988) Extra-pair copulations in black-capped chickadees: the role of the female. Behav $107: 15-23$

Sorrentino V, Gamba M, Giacoma C (2013) A quantitative description of the vocal types emitted in the indri's song. In: Masters JC, Gamba M, Genin F (eds) Leaping ahead: advances in prosimian biology. Springer, New York

Tardif SD (1994) Relative energetic cost of infant care in small bodied Neotropical primates and its relation to infant-care patterns. Am J Primatol 34:133-143

Torti V (2013) Mating system and communication in Indri indri. PhD thesis, University of Torino

Torti V, Sorrentino V, Giacoma C, Gamba M (2010) Acoustic potential for reference-like communication in wild indris. In: Smith ADM, Schouwstra M, De Boer B, Smith K (eds) The evolution of language. World Scientific, pp 505-506 
Trivers RL (1972) Parental investment and sexual selection. In: Campbell B (ed) Sexual Selection and the Descent of Man. Aldine, Chicago, pp 136-179

Wagner RH (1991) The role of extra-pair copulation in razorbill mating strategies. PhD Thesis. University of Oxford

Westneat DF, Sherman PW, Morton ML (1990) The ecology and evolution of extra-pair copulations in birds. Curr ornithol 7:331-369

Wright PC (1990) Demography and life history of free-ranging Propithecus diadema edwardsi in Ranomafana National Park, Madagascar. Int J Primatol 5:835-854

Zahavi A (1975) Mate selection: a selection for a handicap. J Theor Biol 53:205-214 


\begin{tabular}{|c|c|}
\hline Behaviors & Short description \\
\hline Feeding - Eating & $\begin{array}{l}\text { Eating includes all the actions that animals make to take food. The food } \\
\text { usually consist of leaves, flowers, fruits or other plant parts (Powzyk } \\
\text { 1997). The animal can take the food directly with its mouth or it can use } \\
\text { one or both hands to reach and take the food, normally sitting on a } \\
\text { branch or hanging on a trunk. }\end{array}$ \\
\hline Play & $\begin{array}{l}\text { Solitary and social play. Solitary Play includes a number of different } \\
\text { actions, such as running, jumping or wriggling. Sometimes the animal } \\
\text { can interact with inanimate objects, like lianas. In social play two or } \\
\text { more individuals play together in a chaotic and disorderly manner. They } \\
\text { fight without a set pattern of sequences. During these actions they can } \\
\text { produce vocalizations. }\end{array}$ \\
\hline Allogrooming & $\begin{array}{l}\text { An animal inspects the fur of a partner using its fingers or a toothcomb. } \\
\text { The animal that is grooming sits while the target can assume different } \\
\text { postures during the action. More than } 2 \text { individuals can participate in a } \\
\text { grooming session, but individuals always start grooming actions alterna- } \\
\text { tively: they keep a sequence in which they change the roles of groomer } \\
\text { and groomed. Allogrooming can sometimes be associated with social } \\
\text { play. }\end{array}$ \\
\hline Scent mark - Neckband (cheek mark) & $\begin{array}{l}\text { Animals scent-mark by rubbing their neck and the cheeks on horizontal } \\
\text { and vertical substrates, with sebaceous glands located in the neckband } \\
\text { region. }\end{array}$ \\
\hline Scent mark - Anogenital mark & $\begin{array}{l}\text { Animals scent-mark by rubbing their ano-genital region on horizontal } \\
\text { and vertical substrates. }\end{array}$ \\
\hline Vocalizations - Song & $\begin{array}{l}\text { Males and females of the group participate in a chorusing song, mainly } \\
\text { consisting of harmonic frequency modulated notes, usually introduced } \\
\text { by three or four "roars". It plays a role in intergroup communication, } \\
\text { proclaiming the occupation of a territory and transmitting cues for inter- } \\
\text { group avoidance (Maretti et al. 2010; Powzyk and Thalmann 2003; Pol- }\end{array}$ \\
\hline
\end{tabular}




\begin{tabular}{|c|c|}
\hline & lock 1975). \\
\hline Vocalizations - Kiss & $\begin{array}{l}\text { In response to disturbance indris react with calls of medium intensity. In } \\
\text { stress-related contexts these vocalizations are often produced during a } \\
\text { grunt bout or before a song. Kiss is often the first unit of the so-called } \\
\text { "cri d'amour", followed by a wheeze (Maretti et al. 2010). }\end{array}$ \\
\hline Vocalizations - Wheeze & $\begin{array}{l}\text { Typically closely associated with a kiss, the wheeze is a rapid air expul- } \\
\text { sion blown through open lips. It is often emitted in competitive intra- } \\
\text { group situations or in response to potentially dangerous or noxious } \\
\text { stimuli and intruders (Maretti et al. 2010). }\end{array}$ \\
\hline Vocalizations - Roar & $\begin{array}{l}\text { Loud and harsh vocalization used as a standalone vocal signal in the } \\
\text { presence of aerial predators (Maretti et al. 2010). }\end{array}$ \\
\hline Locomotion - Vertical clinging and leaping & $\begin{array}{l}\text { Progression along discontinuous supports, jumping from branch to } \\
\text { branch, making contact with the hands and feet and maintaining a verti- } \\
\text { cal position. }\end{array}$ \\
\hline Reproductive behavior - Approach & $\begin{array}{l}\text { Adult males become agitated and attempt the mount, almost disregard- } \\
\text { ing aggression from the female. }\end{array}$ \\
\hline Reproductive behavior - Reproduction & $\begin{array}{l}\text { The male is standing on its legs, behind the female, introducing his pe- } \\
\text { nis in the vagina. The two animals are in mounting posture and pelvic } \\
\text { thrusting is clearly visible. }\end{array}$ \\
\hline
\end{tabular}

\section{ESM. 1. Description of the behaviors cited in the text, for the species Indri indri.}


Fig.1 Home range of the indri group 3MZ. The Minimum Convex Polygon (MCP 100\%), calculated on the totality of the waypoints collected in 2011, is shown in solid grey. Kernel density estimation $(95 \%)$ is shown with a dotted line. The EPC waypoint was not included in home range size estimates because it was outside the territorial boundaries of group 3MZ. 


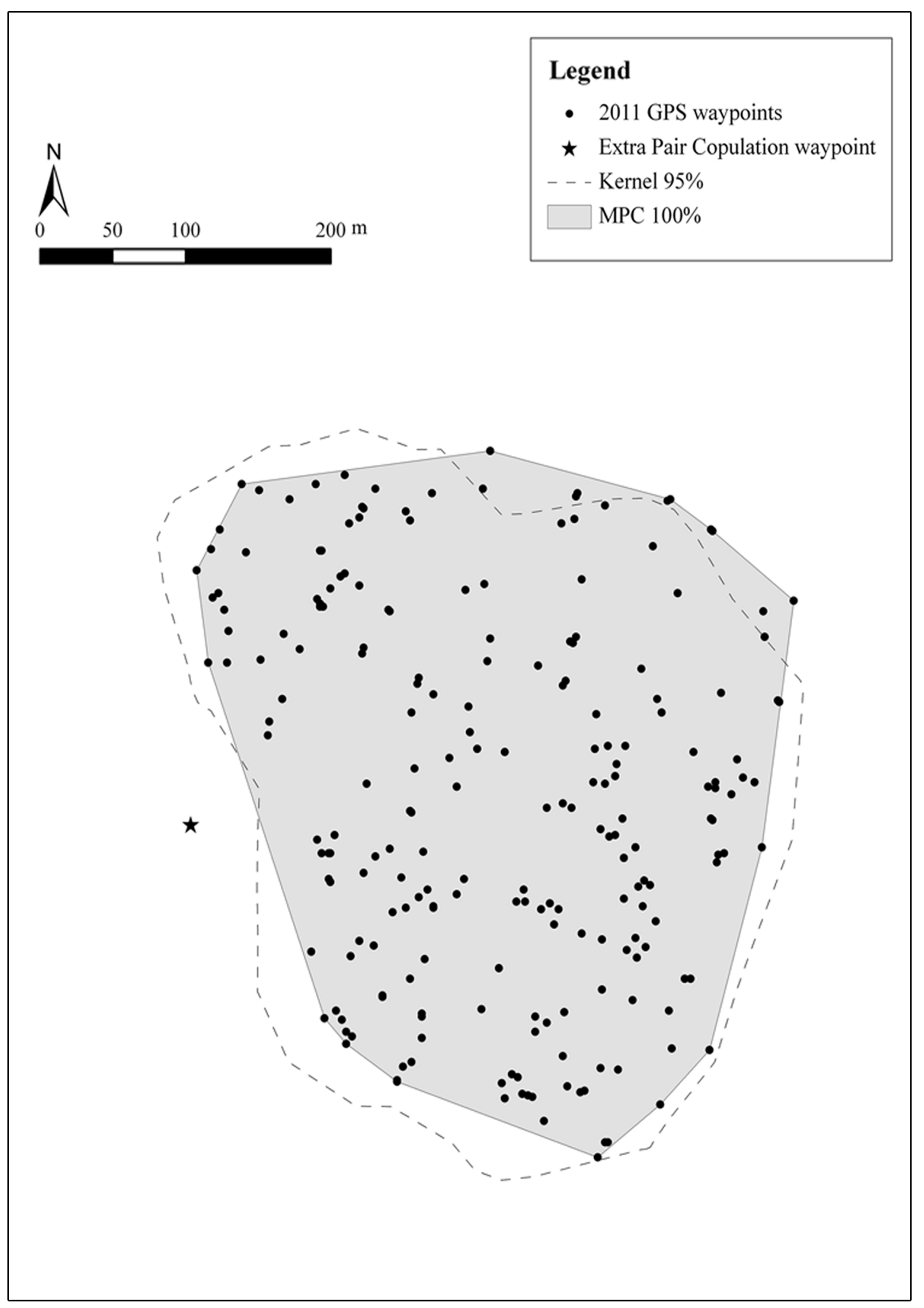

